\title{
Impacts of taxation on Small Scale Industries
}

\author{
Ritesha Das
}

\begin{abstract}
In developing the economy, small and medium-sized businesses play a crucial role. In the last few years, in particular, in the field of creation of jobs, innovation, improving people's living standards and financial contribution to the growth of the country's GDP. The importance of small scale Industries to economic development in any country cannot be underestimated. The challenges of the lack of financial expansive resources, entrepreneurial management skills, unqualified labour, low quality goods production, a lack of market for their products, infrastructure and above all taxation policy that does not promote their potential for growth hinder growth in this sector are hindering its growth.
\end{abstract}

Index Terms - Types of taxes, Role of small scale industries, Impacts of taxation, Tax policies.

\section{INTRODUCTION}

The effect of the tax on small businesses shows that start up companies are facing upward battle in view of allegedly unequal fiscal regimes worldwide. We offer a competitive advantage to established companies. Compared to large companies, businesses pay up to $10 \%$ more of the tax as a percentage of profits, and the newer a company is, the more tax it pays.

It shuts down the world's most invaluable start-up culture. Although many governments provide a smaller-scales tax relief for companies, many still face the same tax regime as large enterprises. A taxing problem is designed to understand the extent of the tax problem, how it affects companies and where solutions can be found.

In addition to the large proportion of economic activities (often mostly) affected by these small to medium-sized enterprises (SMEs) that employ a large proportion of the population working, they also promote creative and vibrant industries in virtually every part of those economies and in every region and territory.

\section{FORMS AND TYPES OF TAXES}

Tax is a compulsory benefaction levied by the government to carry out certain developmental activities (public sector investment ) and non developmental activities ( health and education ) for the benefit of the people. Progressive tax, regressive tax and proportional tax are the types of taxes.

- Progressive taxes are those taxes in which the rate of tax increases with the increase in income.

- Regressive taxes are those taxes in which the rate of tax decreases with the decrease in income.

- Proportional taxes are those taxes in which the rate of tax is

Ritesha Das, Symbiosis Law School, Hyderabad equal for every level of income.

The various forms of taxes are:

- Direct taxes: Direct taxes are those taxes which are levied at the source of income itself. The burden of tax can't be shifted to other person. Income tax, wealth tax , property tax etc are the examples of direct tax.

- Indirect taxes : Indirect taxes are those taxes which are levied on goods and services. The burden of payment can be shifted to another person. Sales tax, service tax, value added tax etc are the examples of indirect tax.

\section{SMALL SCALE INDUSTRIES}

Small scale industries are those industries in which all the production and manufacturing processes are done on a small scale. These industries have an investment outlay of Rs 1 crore. Being managed by a single owner, these industries generally falls under sole proprietorship and due to this, the capital contributed by the sole proprietor is limited and hence these industries generally tend to use labour intensive technology rather than using the capital intensive technology.

\section{A. Role Of Small Scale Industries In India}

- Employment generation : These industries contributes towards employment generation as they promote the use of labour intensive technology and hence generates the need for manpower for manufacturing and production activities. Small scale industries are useful in distributing the income to every sections of the society across various sectors.

- Make in India initiative : Small scale industries provides impetus to make in India initiative. Various small scale industries are involved in producing small components which are to be used by large industries through government e market place and many initiatives are taken under defence procurement policy which will strengthen small scale industries.

- Economic value : Almost $40 \%$ of the GDP of the economy and $45 \%$ of the total exports of the economy is dependent on the small scale industries and these industries are also export oriented which maintains the balance of payment.

- Optimum utilisation of resources : Generally the cost of production is lower in small scale Industries due to the availability of the local resources and low overhead expenses. The products like stationery items, soap, plastic and rubber goods etc offered by the small scale industries are cheaper due to the low cost of production.

- Enhancing skill and technological innovation : Several institutes are imparting skills to small scale 
enterprises and technological innovation along with sustainable credit enhances its value use.

\section{IMPACT OF TAXATION ON SMALL SCALE INDUSTRIES}

Taxation is a very important phenomenon as it generates revenue for the government as : small scale industries form a huge volume and huge number so taxing these enterprises is necessary to generate revenue for the government but to promise the growth certain exemptions are constantly provided by the government from the very first 5 year plan. Although every tax has different impact but in general taxation leads to lower wages, lower profit rates, less credit to industry innovation and skill growth. Taxes like direct tax including Minimum alternative tax, Value added tax are imposed at various rates and they tend to decrease the profit available to the employee which in turn causes less money for wages, lower spending to social development of the employee and decreased rate of investment in skill training and a very lower focus on technological innovation..Taxation reduces profit margin which makes capital investment in machinery, wages, technology less likely to be increased. Saving rates are also reduced due to large revenue forgone by taxes which also decreases investment rate.

On $1^{\text {st }}$ July 2017 , indirect taxes are replaced by GST (goods and service tax). With the advent of GST, tax regime became more easier causing several positive impacts too. Ease of doing business became more efficient with the use of single registration throughout India. GST also removed cascading effect which makes small scale industries more profitable. Small scale industries also avail various benefits through GST composition scheme. But GST rates are in different slabs and are constantly changing causing disruption in the small scale industries.

Although various products made by the Small scale industries are now in zero tax rate but there is a need for more elaborate tax structure. Several past years have seen huge changes in the tax reforms like single window tax filing, yearly tax filing, GST, digitisation causing growth of efficiency to small scale industries.

\section{A. Tax Policies For Small Scale Industries}

According to the Income Tax Act, the taxation policy paid by the proprietor of the small scale industries is mentioned below :

Taxable income slabs upto3 lakhs - nil $(300000+5 \%$ of the total income minus 300000) $+4 \%$ less .

Taxable income slabs upto5 lakhs - 10 lakhs ( Rs 1000000 $+20 \%$ of the total income minus 5 lakh) $+4 \%$ less

Taxable income slabs upto10 lakhs and above ( 10000000 $+30 \%$ of the total income minus 10 lakhs) $+4 \%$ less along with a rebate of Rs 12500 for taxpayers with taxable income upto 5 lakhs under section $87 \mathrm{~A}$ of Income Tax Act. ${ }^{1}$ According to section $80 \mathrm{~J}$ of Income Tax Act, 1961 , "new industrial undertakings, including Small Scale industries are exempted from the payment of income tax on their profits subjected to a maximum of $6 \%$ per annum of their capital employed." Along with that, Corporate Tax rate (25.17\%), minimum added tax (15\%) and sales tax (18\%) are applicable on small scale industries.

Apart from the concessions in the taxation policy, the government has introduced certain incentives for the promotion and development of the small scale industries. Some of the incentives under Central Excise Act are stated below :

- All the Union Territories are immune from sales tax. In some states, it is extended for a period of 5 years .

-Power is supplied to all the industries set up in the regional backward areas at the allowance of 50\%. Some states are exempted from the payment in the initial years of the commencement of the enterprise.

- All those industries set up in the regional backward areas are free from paying taxes for a period of 5 years.

- The tax levied on the goods and services that are brought from one city to another ( Octroi ) has also been eradicated in most of the states.

- These industries are also provided subsidies upto 10$15 \%$ for the investments in the fixed assets. Loans are also provided at a lower rate.

- The National Small Industries Corporation arranges the hire purchases of certain fixed assets like machinery to those industries which are set up in backward regions (including the SSI). The entrepreneurs and the other qualified persons from the regional backward areas pay a lower rate of interest as compared to others.

- "The Transport Subsidy Scheme of 1971 envisages grant of transport subsidy to small scale units in selected areas to the extent of $75 \%$ of the transport cost of raw materials which are brought into and finished goods which are taken out of selected areas."

\section{CONCLUSION AND SUGGESTIONS}

The general tax policy has been adopted by the government to generate revenue considering the fact of their sustainable growth measures. Registered under MSME, these industries can avail of number of schemes, incentives and subsidies. After independence, through Industrial Policy Resolution, government is continuously focusing on SSI , from cottage industry ( $1^{\text {st }}$ year plan $)$ to latest industrial policy, 1991 . The priority sector lending i.e the finance at subsidised rate to small scale enterprises, credit guarantee fund providing collateral free credit, benefits in tendering such as free of cost tender sets, marketing assistance schemes providing assistance to Small scale industries and GST composition scheme are making Small scale industries more profitable and more access to credit is provided to them. No size limits are needed for size-based benefits which are offered regardless of business age or inflexible labour regulation. In order to undo and thus encourage MSMEs to grow, any size opportunity need a sunset clause less than 10 years. Deregulation of limitations on labor laws could generate significantly greater employment compared to other countries, as shown by recent changes in Rajasthan. Guide credit flow to young companies in the flexible high employment market by recalibrating priority sector borrowing guidelines to 
accelerate the generation of jobs.

\section{REFERENCES}

[1] http://businesscasestudies.co.uk/businesstheory/external-environment/how-businesses-are-affected-by-governm ent-policy.html

[2] http://www.isaet.org/images/extraimages/P0416003.pdf

[3] https://pdfs.semanticscholar.org/53f2/5ada306f0c8653fa7d1763ef 102 164f2637e.pdf 